\title{
OCCURRENCE OF COHO SALMON, ONCORHYNCHUS KISUTCH (ACTINOPTERYGII: SALMONIFORMES: SALMONIDAE), OFF THE WEST COAST OF BAJA CALIFORNIA SUR, MEXICO
}

\author{
Edgardo CAMACHO-BAREÑO ${ }^{1}$, Xchel G. MORENO-SANCHEZ ${ }^{1}$, \\ and Deivis S. PALACIOS-SALGADO ${ }^{2 *}$ \\ ${ }^{1}$ Instituto Politécnico Nacional, Centro Interdisciplinario de Ciencias Marinas, \\ La Paz, Baja California Sur, México \\ ${ }^{2}$ Escuela Nacional de Ingeniería Pesquera, Colección ictiológica, San Blas, Nayarit, México 63740
}

\begin{abstract}
Camacho-Bareño E., Moreno-Sanchez X.G., Palacios-Salgado D.S. 2014. Occurrence of coho salmon, Oncorhynchus kisutch (Actinopterygii: Salmoniformes: Salmonidae), off the west coast of Baja California Sur, Mexico. Acta Ichthyol. Piscat. 44 (3): 259-261.
\end{abstract}

\begin{abstract}
We provide the first record of a coho salmon, Oncorhynchus kisutch (Walbaum, 1792), off the western coast of Baja California Sur, Mexico, approximately $690 \mathrm{~km}$ south of the previously reported distribution in the Northwest Pacific. The specimen was captured in the regional commercial fishery. It was a female, $520 \mathrm{~mm}$ standard length, weighing $1855 \mathrm{~g}$. Morphometric and meristic data are presented.
\end{abstract}

Keywords: first record, silver salmon, locality record, Las Barrancas, Pacific Decadal Oscillation, upwelling index

Pacific salmon of the genus Oncorhynchus are commercially important species, characterized by an anadromous life cycle, in which the adults move upriver to spawn and then die (Pauly 2004). In the Eastern Pacific, salmon are represented by five species: coho salmon, Oncorhynchus kisutch (Walbaum, 1792); pink salmon Oncorhynchus gorbuscha (Walbaum, 1792); chum salmon, Oncorhynchus keta (Walbaum, 1792); sockeye salmon, Oncorhynchus nerka (Walbaum, 1792); and Chinook salmon, Oncorhynchus tshawytscha (Walbaum, 1792) (see Schiewe and Kareiva 2000). Only O. kisutch and O. tshawytscha are distributed in the temperate waters off the western Baja California peninsula, Mexico (Byers 1942, Messersmith 1965, De La Cruz-Agüero 1999). Coho salmon, Oncorhynchus kisutch, is the most widely distributed, although the less abundant, salmon species in the Pacific (Sandercock 1991, Schiewe and Kareiva 2000). Its known distribution in North America ranges from Point Hope in Alaska to Camalu Bay $\left(30^{\circ} 50^{\prime} \mathrm{N}\right.$; $116^{\circ} 11^{\prime} \mathrm{W}$ ) in Baja California, Mexico (Messersmith 1965, Loiselle and Thoney 2003).

A specimen of coho salmon was captured in July 2013 by artisanal fishermen in Las Barrancas $\left(25^{\circ} 59^{\prime} \mathrm{N}\right.$, $112^{\circ} 11^{\prime} \mathrm{W}$ ), off the western coast of Baja California Sur, Mexico, approximately $690 \mathrm{~km}$ south of the reported distribution limit (Fig. 1). Captures were done using 6" gill-

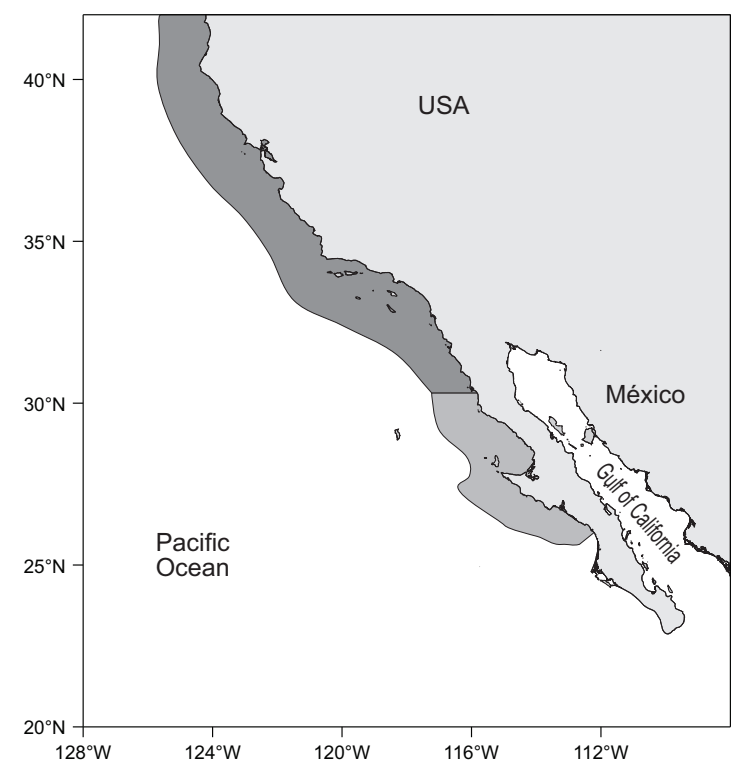

Fig. 1. Map showing the presently described range extension of the coho salmon, Oncorhyncus kistuch; The habitat expansion is of approximately $690 \mathrm{~km}$; The black fringe shows the previously known distribution; last reported distribution to Camula BC (1); light grey fringe, range expansion to Las Barrancas BCS (2)

\footnotetext{
* Correspondence: Dr. Deivis S. Palacios Salgado, Escuela Nacional de Ingeniería Pesquera, Colección ictiológica, Apartado Postal 10, San Blas, Nayarit. México 63740, phone: (+323) 231-21-20, e-mail: (DSPS) palaciossalgado@gmail.com, (ECB) ecabe87@gmail.com, (XGMS)xchel.moreno@gmail.com.
} 
nets set at $10 \mathrm{~m}$ depth, approximately two $\mathrm{km}$ from the coast. The specimen was identified using the keys by Miller and Lea (1976) and Eschmeyer et al. (1983). Once identified, it was catalogued and stored in the ichthyological collection of the Escuela Nacional de Ingeniería Pesquera (ENIP-CI481), San Blas, Nayarit, Mexico.

The Oncorhynchus kisutch specimen (Fig. 2) was a female, 590-mm long, weighing $1855 \mathrm{~g}$ (Table 1). This species can be easily distinguished from $O$. gorbuscha and $O$. keta by the presence of teeth on the tongue and by the number of pyloric caeca (Table 1). It can be distinguished from $O$. nerka by the number of gill rakers (21 in O. kisutch vs. $28-40$ in $O$. nerka), and by the presence of teeth at the base of the tongue. It differs from $O$. tshawytscha in the number of pyloric caeca (71 in $O$. kisutch vs. $140-185$ in $O$. tshawytscha), and in the gum coloration (white in $O$. kisutch vs. black in O. tshawytscha) (Miller and Lea 1976, Eschmeyer et al. 1983).

Coho salmon reach sexual maturity at between two and four years old (Loiselle and Thoney 2003). They generally enter freshwater systems between August and January, and move upstream to spawn in the coastal rivers and small tributaries of the great river systems. Juveniles remain in the smaller tributaries approximately 18 months

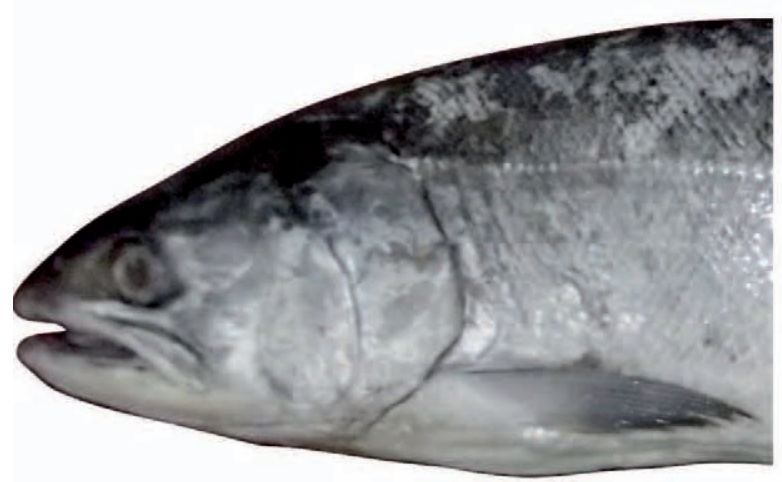

before starting to migrate towards the ocean during the spring of their second year of life. They then tend to remain over the continental platform, feeding and growing in marine waters located approximately at the same latitude as their river of origin (Sandercock 1991, Schiewe and Kareiva 2000). The presently described specimen, however, was captured $690 \mathrm{~km}$ south from the limit of its known distribution, establishing thus a significant expansion of its habitat. The area lacks river tributaries that could serve as natural habitat for this species, so that the habitat expansion could be a consequence of the environment, which affects directly the abundance and distribution of marine species (De La Cruz-Agüero 1999, Hopkins and Cech 2003, Fernández et al. 2011). It has been mentioned that at the watershed level there is a positive correlation between ocean and atmosphere indices such as the Pacific Decadal Oscillation (PDO), and the time series of salmon catches in the northern Pacific (Mantua et al. 1997). It has also been observed that salmon abundance increases as a consequence of the increase in the coastal upwelling index (Scarnecchia 1981, Mueter et al. 2002, Lawson et al. 2004).

The presence of Oncorhynchus kisutch in waters close to Las Barrancas could be the result of a combination
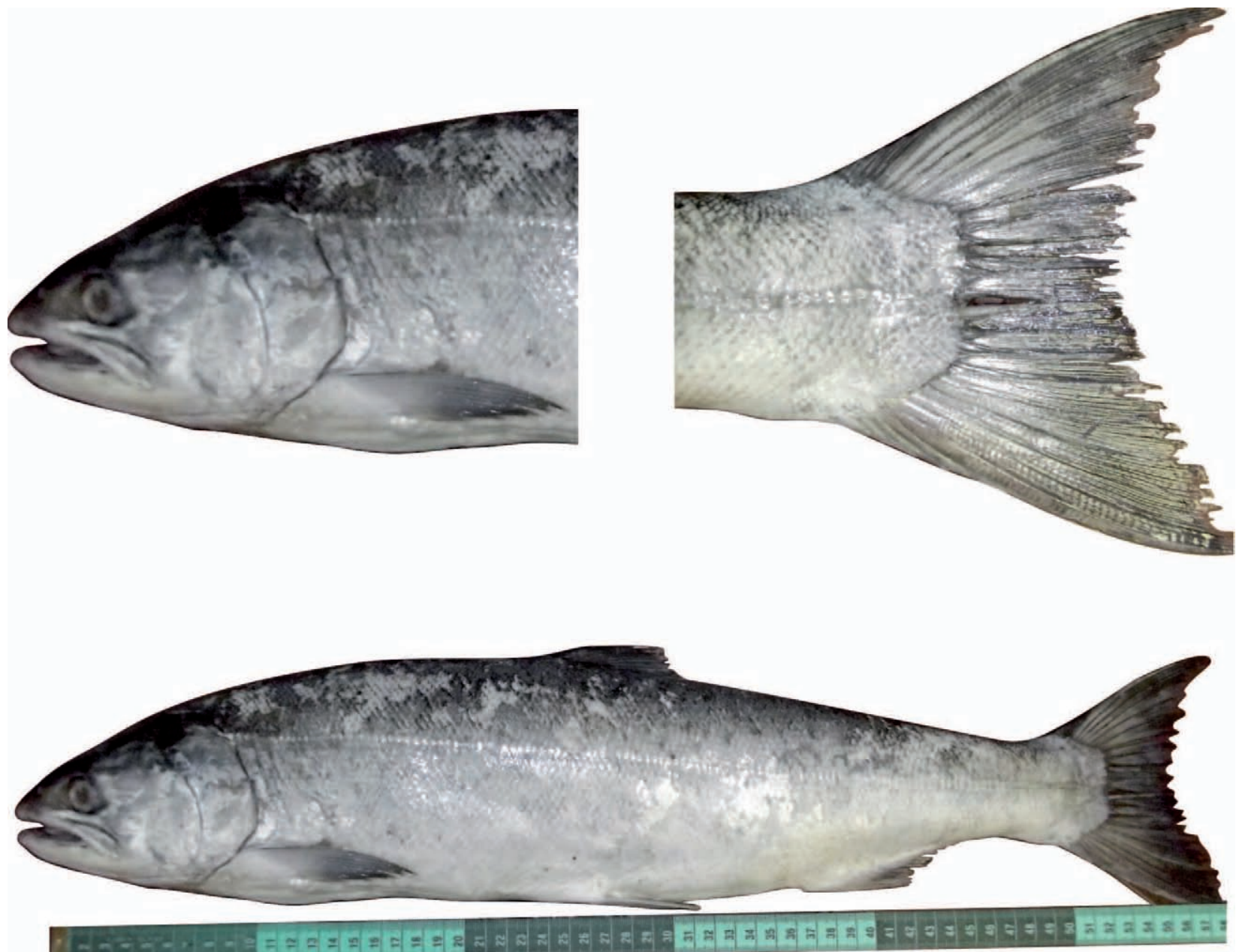

Fig. 2. Female of coho salmon, Oncorhynchus kisutch (ENIP-CI-387), $520 \mathrm{~mm}$ SL, collected at Las Barrancas, Baja California Sur, Mexico, on 30 July 2013 
Table 1 Eschmeyer W.N., Herald E.S., Mammann H., Gnagy J.

Morphometric and meristic characteristics of coho salmon, Oncorhynchus kisutch, from the Pacific coast of the Baja California Peninsula, Mexico

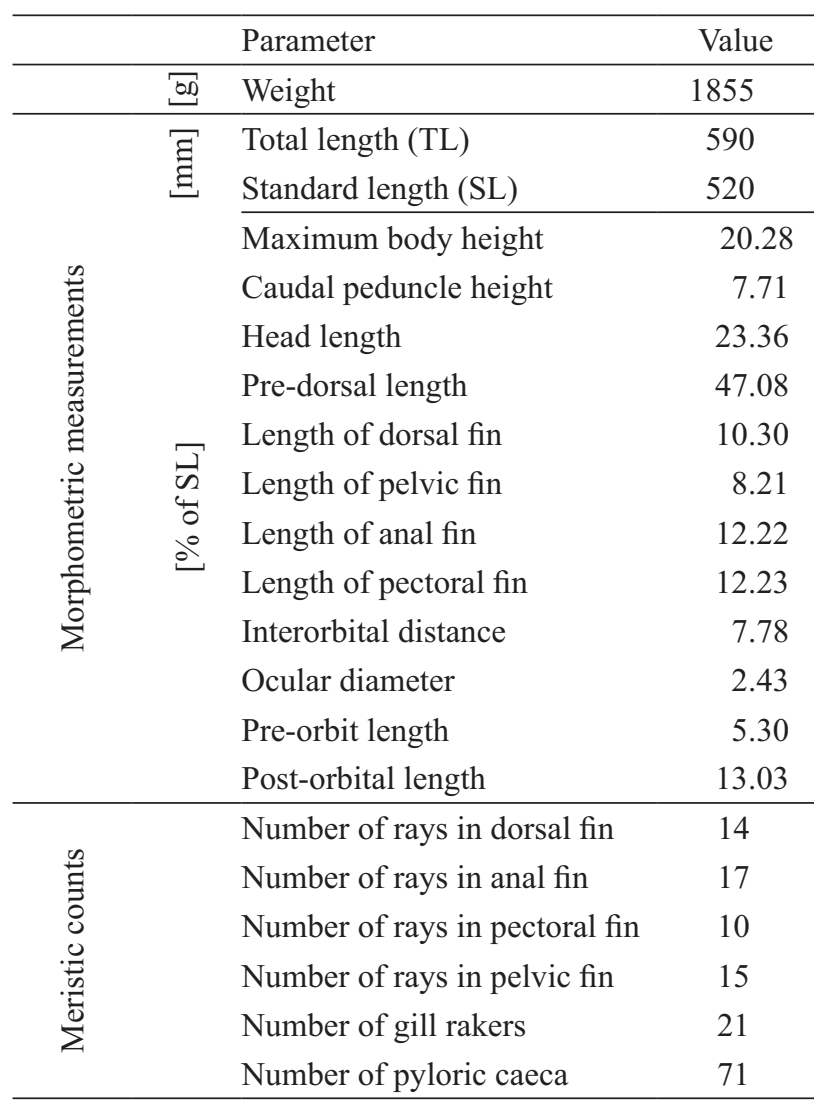

of increased upwelling and negative PDO values that have affected the western coast of the Baja California Peninsula (Perry et al. 2005). It is probable that the $O$. kisutch specimen found a cold water corridor rich in nutrients, with availability of potential prey that allowed it to enter waters south of the area it normally inhabits. However, there are no data at present to adequately support this hypothesis.

\section{ACKNOWLEDGEMENTS}

We thank the technical support of the fishermen from community of Las Barrancas BCS, especially to Gaudencio Meza Mayoral, Leonel Meza Canett, and to Tomás Camacho Bareño, technical advisor of SCPP Puerto Chale SCL. ECB thanks Consejo Nacional de Ciencia y Tecnologia (CONACyT) and the Institutional Program of Research Training (PIFI-IPN). XGMS thanks the Instituto Politécnico Nacional (IPN) for economic support through the Contratación por Excelencia. DSPS and XGMS are grateful for research grants from SNICONACyT.

\section{REFERENCES}

Byers R.D. 1942. Salmon caught in Mexican waters. California fish and Game 28 (4): 217.

De La Cruz-Agüero J. 1999. A first Mexican record of the chinook salmon, Oncorhynchus tshawytscha. California Fish and Game 85 (2): 77-78.
1983. A field guide to the Pacific coast fishes of North America. Hougthon Mifflin, Boston, MA. USA.

Fernández M., Hernández D., Roux A. 2011. Analysis of the relationship between relative abundance of mature, impregnated females of Pleoticus muelleri (Bate, 1888) (Crustacea, Decapoda) y environmental variables through statistical models. Latin American Journal of Aquatic Research 39 (1): 1-15. DOI: 10.3856/vol39-issue1-fulltext-1

Hopkins T.E., Cech jr. J.J. 2003. The influence of environmental variables on the distribution y abundance of three elasmobranchs in Tomales Bay, California. Environmental Biology of Fishes 66 (2): 279-291. DOI: 10.1023/A:1023907121605

Lawson P.W., Logerwell E.A., Mantua N.J., Francis R.C., Agostini V.N. 2004. Environmental factors influencing freshwater survival and smolt production in Pacific Northwest coho salmon (Oncorhynchus kisutch). Canadian Journal of Fisheries and Aquatic Sciences 61 (3): 360-373. DOI: 10.1139/f04-003

Loiselle P.V., Thoney D.A. 2003. Fishes I-II. In: Hutchins M., Thoney D.A., Loiselle P.V., Schlager N. (eds.). Grzimek's Animal Life Encyclopedia. 2nd edn. Vol. 4-5. Gale Group, Farmington Hills, MI, USA.

Mantua N.J., Hare S.R., Zhang Y., Wallace J.M. 1997. A Pacific interdecadal climate oscillation with impacts on salmon production. Bulletin of the American Meteorological Society 78 (6): 1069-1079. DOI: 10.1175/15200477(1997)078<1069:APICOW>2.0.CO;2

Messersmith J.D. 1965. Southern range extensions for chum and silver salmon. California Fish and Game 51 (3): 220.

Miller D.J., Lea R.N. 1976. Guide to the coastal marine fishes of California. Fisheries Bulletin No. 157.

Mueter F.J., Peterman R.M., Pyper B.J. 2002. Opposite effects of ocean temperature on survival rates of 120 stocks of Pacific salmon (Oncorhynchus spp.) in northern and southern areas. Canadian Journal of Fisheries and Aquatic Sciences 59 (3): 456-463. DOI: 10.1139/f02-020

Pauly D. 2004. Darwin's fishes. An encyclopedia of ichthyology, ecology and evolution. Cambridge University Press Cambridge, UK.

Perry A.L., Low P.J., Ellis J.R., Reynolds J.D. 2005. Climate change and distribution shifts in marine fishes. Science $\mathbf{3 0 8}$ (5730): 1912-1915. DOI: 10.1126/science. 1111322

Sandercock F.K. 1991. Life history of coho salmon (Oncorhynchus kisutch). Pp. 396-445. In: Groot C., Margolis L. (eds.) Pacific salmon life histories. University of British Columbia Press, Vancouver, BC, Canada.

Scarnecchia D.L. 1981. Effects of streamflow and upwelling on yield of wild coho Salmon (Oncorhynchus kisutch) in Oregon. Canadian Journal of Fisheries and Aquatic Sciences 38 (4): 471-475. DOI: 10.1139/f81-066

Schiewe M.H., Kareiva P. 2000. Salmon. Pp. 233-243. In: Levin S.A. (ed.) Encyclopedia of biodiversity. Academic Press, San Diego, CA, USA.

Received: 17 February 2014

Accepted: 6 August 2014

Published electronically: 15 October 2014 